\title{
THE BROWN DWARF: A RECENT ADDITION TO THE VARIETIES AND FORMS OF THE COCONUT PALM GROWN IN SRI LANKA
}

\author{
R R A Peries \\ Coconut Research Institute, Lunuwila, Sri Lanka
}

The endemic coconut germplasm of Sri Lanka have been categorized into three main varieties Viz. typica, nana and aurantiaca by Liyanage (1958) based on their morphological characters and breeding behavior.

The variety nana or the dwarf, also known as Kundira to the local farmer, included three colour forms viz. form red (Regia), form yellow (Eburnea) and form green (Pumilla). Except for these three colour forms no other intermediate forms had been reported.

Under the germplasm collection and conservation programme of the Coconut Research Institute of Sti Lanka, a single palm of a brown coloured dwarf was initially identified in a home garden near Madampe in the Puttalam district (Peries, 1991). Later a few palms showing similar morphological characters and breeding behavior were located in Kirimetiyana, Marawila and Mawathagama within the coconut triangle, with most cases as a single tree in a home garden.

The original palms were initially inspected for their breeding behavior by observing the male and female phases of the inflorescence, and other common morphological characters such as stature, stem girth, presence of absence of the bole, length and width of fronds and leaflets, nut components, inflorescence and the germination speed.

The short stature $(4 \mathrm{~m})$, narrow stem, absence of a bole, narrow and short fronds and leaflets, the small nut size and weight and the presence of a large number of female flowers (average 80 per inflorescence and an average of 4 per spikelet) and the overlapping male and female phases of the inflorescence indicative of self pollinating behavior, which are the typical characteristics of dwarfs, confirmed the identified palm as another colour form of the variety nana. The results of the Fruit Component Analysis carried out for nuts of the original palms of the form dwarf brown are presented in Table 1. 
Table 1. Fruit characteristics of the dwarf brown form of the variety nana.

\begin{tabular}{lcc}
\hline Fruit character & Mean & SD \\
\hline Fruit weight $(\mathrm{g})$ & 569.1 & 64.17 \\
Husk weight $(\mathrm{g})$ & 257.7 & 31.07 \\
Nut weight $(\mathrm{g})$ & 311.4 & 59.52 \\
Split nut weight $(\mathrm{g})$ & 248.8 & 36.88 \\
Volume of nut water $(\mathrm{ml})$ & 63.5 & 28.40 \\
Thickness of shell $(\mathrm{mm})$ & 2.4 & 00.20 \\
Thickness of kernel $(\mathrm{mm})$ & 8.6 & 01.13 \\
Fresh weight of kernel $(\mathrm{g})$ & 173.0 & 25.14 \\
Dry weight of kernel $(\mathrm{g})$ & 88.7 & 15.81 \\
Estimated copra weight $(\mathrm{g})$ & 99.5 & \\
\hline
\end{tabular}

Table 2. Varieties and forms of the coconut palms grown in Sri Lanka (After Liyanage, 1958).

\begin{tabular}{|c|c|c|}
\hline Variety & Breeding habit & Form \\
\hline Typica (Tall) & Out-breeding & $\begin{array}{l}\text { Typica } \\
\text { Bodiri } \\
\text { Ran thembili } \\
\text { Gon thembili } \\
\text { Nawasi } \\
\text { Pora pol } \\
\text { Kamandala } \\
\text { Dikiri pol }\end{array}$ \\
\hline $\begin{array}{l}\text { Nana (Dwarf) } \\
\text { (Kundira) }\end{array}$ & In-breeding & $\begin{array}{l}\text { Pumilla (dwarf green) } \\
\text { Eburnea (dwarf yellow) } \\
\text { Regia (dwarf red) } \\
\text { Braune (dwarf brown) }\end{array}$ \\
\hline Aurantiaca & Iri-breeding & $\begin{array}{l}\text { Thembili (King coconut) } \\
\text { Nawasi thembili }\end{array}$ \\
\hline
\end{tabular}

These palms were then self pollinated for purification and multiplication and for conservation to be used in future breeding programme. The seedlings raised from selfed nuts produced seedlings with typical dwarf characteristics i.e. early leaf splitting, with its specific brownish colour on the petiole and young seedling stem 
confirming the genetic identify for colour and other dwarf seedling characters. Further this phenomenon elucidates the fact that the dwarf brown palms identified, show homozygosity for the character colour. The majority of seedlings raised from open-pollinated nuts also produced similar seedlings further confirming the predominantly self-pollinating behaviour.

However, the germination speed of the nuts showed a slight deviation from the reported germination speed for other colour forms of the dwarf (Fernando et al, 1994), initiating sprouting by about the 5th week after laying and reaching $80 \%$ germination within 14-15 weeks.

A further and systematic investigation and evaluation of the dwarf brown will be carried out in future to study its usefulness as a source of breeding material. Characters such as growth habit, flowering period, yield of nuts, yield of copra and tolerance to drought and resistance to pest and diseases will be evaluated.

This form has not yet been studied for its combining ability with the Sri Lanka tall, and may have potential for the future in producing a high yielding hybrid coconut, in the coconut breeding programme of Sri Lanka.

The updated list of varieties and forms of coconuts in Sri Lanka is given in Table 2.

\section{REFERENCES}

Fernando, W.M.U., Peiris T.S.G., and Wickramaratne, M.R.T (1994). Variation in some seedling characters of three different coconut cultivars and their use in identification in the nursery, $\operatorname{Cocos}$ 9: 23-29.

Liyanage, D.V., (1958). Varieties and forms of the coconut palm grown in Ceylon, Ceylon Coconut Quarterly, 9: 1-10.

Peries, R.R.A., (1991). Report of the Genetics and Plant Breeding Division. In Report for 1991, Coconut Research Institute, Sri Lanka. 